\title{
Erratum to: Testing of Communicating Systems
}

\author{
Gyula Csopaki ${ }^{1}$, Sarolta Dibuz ${ }^{2}$, and Katalin Tarnay ${ }^{3}$ \\ 1 Technical University of Budapest, Hungary \\ 2 Ericsson Hungary, Hungary \\ 3 Nokia Hungary, Hungary \\ 4 Ericsson Telecommunication Ltd., Hungary
}

\section{Erratum to: \\ G. Csopaki et al. (Eds.) \\ Testing of Communicating Systems \\ DOI: $10.1007 / 978-0-387-35567-2$}

The book was inadvertently published with an incorrect name of the copyright holder. The name of the copyright holder for this book is: (c) IFIP International Federation for Information Processing. The book has been updated with the changes.

The updated original online version for this book can be found at DOI: $10.1007 / 978-0-387-35567-2$ 